\title{
Seroreactivity of hepatitis B and C in a tertiary care hospital ASCOMS
}

\author{
Jyoti Kohli ${ }^{1}$, Ajay Puri ${ }^{*}$, Bella Mahajan ${ }^{3}$ \\ ${ }^{1,2}$ Associate Professor, ${ }^{3}$ Professor, ${ }^{1,3}$ Dept. of Microbiology, ${ }^{2}$ Dept. of Biochemistry, Acharya Shri Chander College of Medical Sciences
} Jammu (ASCOMS), J\&K, India

*Corresponding Author: Ajay Puri

Email: puria062@gmail.com

\begin{abstract}
Background: Hepatitis B and C are globally emerging health problems. Being Hepatitis B and C are parenterally transmitted viruses both resulting in liver cirrhosis and hepatocellular carcinoma. Both accounting for the substantial proportion of hepatic diseases worldwide. Although both are hepatotropic viruses both are sharing common modes of transmission and mostly affect the young population. Prevalence of Hepatitis B in India is 3.7\% and Hepatitis C is $1 \%$. Hepatitis B is the second most common cause of acute viral hepatitis in India. Chance of transmission of Hepatitis B by needle stick injury is $30 \%$ and of Hepatitis $\mathrm{C}$ is $3 \%$. Intravenous drug abusers were found to be most common mode of transmission of Hepatitis $\mathrm{C}$.

Aims: As both Hepatits B, and C are parenterally transmitted infections and land up into chronicity. To prevent their complications the present study was done to screen out these cases at the very early stage with the test with high sensitivity and specificity.

Materials and Methods: The presence of HBsAg and anti HCV antibodies were studied serologically in patients blood by Electro chemiluminescence immune-assay method.

Results: The seroreactivity of positive cases were observed.

Conclusion: Henceforth seroreactivity of both the viruses studied among different age groups in both the sexes to initiate the treatment at right time to prevent its long term complications such as chronicity and for good prognosis by highly sensitive and specific test.
\end{abstract}

Keywords: Anti-HCV antibodies, Electrochemiluminescence immunoassay (ECLIA), Hepatitis B surface antigen (HBsAg), Hepatocellular carcinoma (HCC), Liver cirrhosis.

\section{Introduction}

Hepatitis infection is a serious clinical problem because of its worldwide distribution and potential adverse sequelae. It is particularly important in Asian- Pacific region where the prevalence is high. Hepatitis $\mathrm{B}$ and $\mathrm{C}$ is most commonly prevalent among those, both are parenterally transmitted. About 350 million people develop the risk of chronic liver diseases like cirrhosis of liver and hepatocellular carcinoma worldwide. Health care workers are also at risk of these infections due to needle stick injury. Although both viruses differing in their nucleic acid sequence pattern but affecting the young population mostly. Hepatitis $\mathrm{C}$ infects $3 \%$ of world population but in our country its prevalence is 0.8 $1.5 \% .^{1}$ Hepatitis C mostly encountered among intravenous drug abusers and also in patients on long term dialysis. Both Hepatitis B and C are sexually transmitted also. There is a need to formulate a health educational curriculum targeting not only the high risk population but also the general population regarding the modes of transmission of these viruses. Adopting the dual approach of treating the old cases and decreasing the incidence of new cases would help in curtailing the disease and decreasing the related mortality. ${ }^{2}$ $\mathrm{HCV}$ is known to cause both acute and chronic infection in humans and unlike $\mathrm{HBV}, 80 \%$ of acute $\mathrm{HCV}$ infection in adults can lead onto chronic viremia. Of these persons with chronic infection, $30 \%$ will develop progressive liver disease culminating in cirrhosis of liver and or hepatocellular carcinoma (HCC). ${ }^{3}$ The estimated prevalence of $\mathrm{HCV}$ in India is $0.5-1.5 \% .^{4}$ Despite the low prevalence of $\mathrm{HCV}$, India with its large population accounts for a significant proportion of global HCV burden. ${ }^{5}$ Approximately, 12-18 million people are thought to be infected with $\mathrm{HCV}$ in India. ${ }^{6}$ In the part of the world, majority of HBV infection is acquired perinatally or in early childhood if mother is sero-reactive. The prevalence of Chronic Hepatitis B in India is in the intermediate range with an estimated 40 million people infected. Most adults infected with these viruses recover but $5-10 \%$ are unable to clear these viruses and become chronically infected so there is need to evaluate for the underlying cause of hepatitis for the treatment to be initiated at right time to prevent the complications and for prognosis also.

\section{Materials and Methods}

A retrospective study was conducted in the department of Microbiology and collaboration with department of Biochemistry on 3500 patients attending the out patient department of Medicine of Acharya Shree Chander College of Medical Sciences \& Hospital Jammu for the duration of 1 year from March 2018 to April 2019 after seeking permission from institutional board with signs and symptoms of hepatitis and with deranged liver function tests.

\section{Inclusion criteria}

Patients with history of raised bilirubin and deranged liver function tests, patients on dialysis, immunocompromised patients, unhealed ulcers, intravenous drug abusers, patients admitted for surgical procedures.

\section{Exclusion criteria}

Normal healthy asymptomatic individuals, patients with hepatitis $\mathrm{A}$ and $\mathrm{E}$, chronic liver disorders. $2 \mathrm{ml}$ venous blood sample were withdrawn under aseptic conditions. 
HBsAg and ant- HCV antibodies were detected by electrochemiluminescense immunoassay and results were expressed as IU/ml - a new fully automated version of quantification of these viruses. ${ }^{7}$ Liver function tests were estimated by Cobas 311 autoanalyser. Statistical analysis was done. Quantitative HBsAg and anti-HCV antibodies are the alternate biomarker for the estimation of these viruses as compared to DNA or RNA quantification and are cheaper method of monitoring these.

\section{Result}

Total of 3500 patients with and without clinical presentation of hepatitis were studied for HBsAg and HCV. Both were detected by ECLIA method i.e. electrochemiluminescense method. Out of these 2100 were found to be males and 1400 were females as shown in Table 1 . Male- Female ratio was found to be 1.5 in the study group. The percentage of reactive cases of Hepatitis $B$ and Hepatitis $C$ were estimated among these and also in terms of sex ratio was seen as shown in Table 2 and 3 where number and percentage of reactive cases was estimated and sex wise distribution of these cases was seen respectively. 38 cases out of 3500 turned to be HBsAg reactive and male - female ratio among these is 23:15. The percentage of reactive males and females for HBsAg reactive was also calculated as shown in Table 3. Hepatitis $C$ reactive cases were found to be 89 cases out of 3500. Males were mostly affected ones i.e 77 as shown in Table 2 and 3. Table 4 showed age-wise distribution of reactive cases of $\mathrm{HBs} \mathrm{Ag}$ and $\mathrm{HCV}$ and maximum number of reactive cases were seen in the age group of 20- 40 years. Seroreactivity of HBsAg and $\mathrm{HCV}$ in different places was also compared in Table 4.

Table 1: Sex wise distribution of total cases

\begin{tabular}{|l|c|c|}
\hline Patients tested & Number & Percentage \\
\hline Male & 2100 & $60 \%$ \\
\hline Female & 1400 & $40 \%$ \\
\hline
\end{tabular}

Table 2: Number and percentage of reactive cases

\begin{tabular}{|l|c|c|c|c|}
\hline Total No. of cases & $\begin{array}{c}\text { No. of } \mathrm{HBsAg} \\
\text { reactive }\end{array}$ & $\begin{array}{c}\text { \% age of } \mathrm{HBsAg} \\
\text { reactive }\end{array}$ & $\begin{array}{c}\text { No. of } \mathbf{H C V} \\
\text { reactive }\end{array}$ & $\begin{array}{c}\text { \% age of } \mathrm{HCV} \\
\text { reactive }\end{array}$ \\
\hline 3500 & 38 & 1.08 & 89 & 2.5 \\
\hline
\end{tabular}

Table 3: Sex wise prevalence of $\mathrm{HBs} A g$ and $\mathrm{HCV}$ reactive cases

\begin{tabular}{|l|c|c|c|c|c|}
\hline Gender & $\begin{array}{c}\text { Total no. of } \\
\text { cases }\end{array}$ & $\begin{array}{c}\text { No.HBsAg } \\
\text { reactive }\end{array}$ & $\begin{array}{c}\text { \%age 0f HBsAg } \\
\text { reactive }\end{array}$ & $\begin{array}{c}\text { No. of HCV } \\
\text { reactive }\end{array}$ & $\begin{array}{c}\text { \%age HCV } \\
\text { reactive }\end{array}$ \\
\hline Male & 2100 & 23 & 1.09 & 77 & 2.2 \\
\hline Female & 1400 & 15 & 1.07 & 12 & 0.34 \\
\hline
\end{tabular}

Table 4: Age wise distribution of reactive cases of hepatitis B and hepatitis C

\begin{tabular}{|l|c|c|c|c|}
\hline Age in years & $\begin{array}{c}\text { No. of HBsAg } \\
\text { reactive }\end{array}$ & $\begin{array}{c}\text { \%age of HBsAg } \\
\text { reactive }\end{array}$ & $\begin{array}{c}\text { No. of HCV } \\
\text { reactive }\end{array}$ & $\begin{array}{c}\text { \%age of HCV } \\
\text { reactive }\end{array}$ \\
\hline $0-20$ & 4 & 0.11 & 6 & 0.17 \\
\hline $20-40$ & 15 & 0.42 & 59 & 2 \\
\hline $40-60$ & 11 & 0.31 & 18 & 0.05 \\
\hline$>60$ & 8 & 0.22 & 6 & 0.17 \\
\hline
\end{tabular}

Table 5: Comparison of seroreactivity of HBsAg and HCV

\begin{tabular}{|l|c|c|c|c|}
\hline Author & Year of study & Place & $\begin{array}{c}\text { Percentage of } \\
\text { HBsAg }\end{array}$ & $\begin{array}{c}\text { Percentage of anti- } \\
\text { HCV }\end{array}$ \\
\hline Bukhari & 2003 & Pakistan & 27.8 & 61.1 \\
\hline Devi et al & 2004 & Manipur & 42.3 & 46.6 \\
\hline Singh et al & 2004 & Chandigarh & 30 & 48 \\
\hline Chakravati & 2005 & Delhi & 33.33 & 25.75 \\
\hline Bakshi et al & 2012 & Patiala & 28 & 41 \\
\hline Present study & 2019 & Jammu & 1.08 & 2.5 \\
\hline
\end{tabular}




\section{Discussion}

Both Hepatitis B and Hepatitis C infections mostly accounts for chronic liver diseases because these two hepatotropic viruses share same modes of transmission. In our study the reactive cases of $\mathrm{HBs} \mathrm{Ag}$ and $\mathrm{HCV}$ were found to be 38 $(1.08 \%)$ and $89(2.5 \%)$ respectively as compared to the study done by Rupinder $\mathrm{K} \mathrm{Bakshi}{ }^{8}$ in 2012 where seroprevalence of $\mathrm{HBsAg}$ and anti $\mathrm{HCV}$ in chonic liver diseases was $28 \%$ and $41 \%$ respectively. In the present study there was no difference of sex ratio of reactive cases of Hepatitis B i.e. among females (15 out of 1400, 1.07\%) than males, (23 out of $2100,1.09 \%$ ) while $\mathrm{HCV}$ was higher among males (77 out of $2100,2.2 \%$ ) than females (12 out of $1400,0.34 \%$ ) where as study done by Joy Baseke and Monica Musenero et $\mathrm{al}^{9}$ revealed that Hepatitis B was more prevalent among women i.e. $22.8 \%$ and $6.2 \%$ in men where as $\mathrm{HCV}$ rate was higher among men i.e. $12.5 \%$ than women $1.8 \%$. In the present study the table number IV revealed that both hepatitis $\mathrm{B}$ and Hepatitis $\mathrm{C}$ infections were most commonly observed among adults i.e. 20- 40 years of age group which was similar to other studies. Based on history it was observed that Hepatitis B infection was most commonly sexually transmitted and Hepatitis $\mathrm{C}$ infection was seen among intravenous drug abusers and patients on hemodialysis were suffering from either of these viral infections. Intravenous and percutaneous drug abuse is a significant problem in Northeast India ${ }^{10}$ due to unsafe injection practice ${ }^{11}$. In our present study although the seroreactivity rate was less as compared to other studies done in different places as shown in table number $\mathrm{V}$ but it is significant and not to be neglected. Bukhari et $\mathrm{al}^{12}$ in 2003 observed prevalence rate of $\mathrm{HBsAg}$ and $\mathrm{HCV}$ positive in Pakistan was $27.8 \%$ and $61.1 \%$, Devi et al ${ }^{13}$ in 2004 in Manipur found that rate was $42.3 \%$ and $46.6 \%$ respectively. Whereas Singh et al ${ }^{14}$ in 2004 in Chandigarh observed that prevalence rate of positive cases of HBsAg and HCV was $30 \%$ and $48 \%$ and Chakravati ${ }^{15}$ in 2005 in Delhi found that positivity rate for $\mathrm{HBsAg}$ and $\mathrm{HCV}$ was $33.33 \%$ and $25.75 \%$ respectively. Another study done by Shivani Garg, et $\mathrm{al}^{16}$ in 2012 showed that 71 out of 7874 were tested positive for anti-HCV antibodies i.e. $9.02 \%$. Suri et al ${ }^{17}$ in a tertiary care centre of North India the prevalence rate was $13.25 \%$ in 2010 and $14.27 \%$ in 2011 respectively. Another study done by Panigrihi et $\mathrm{al}^{18}$ at AIIMS, New Delhi the prevalence rate was found to be $13.83 \%$ where as it was found to be $1.7 \%$ in study done by Sinha P et al at Jaipur ${ }^{19}$ and $1.57 \%$ in study done by Mishra $\mathrm{S}$ et al at $\mathrm{Oriss}^{20}$ for $\mathrm{HCV}$. Both viruses should be screened out as early as possible to prevent chronicity of liver diseases and its complications.

\section{Conclusion}

Viral hepatitis cause acute and chronic sequelae worldwide. This is responsible for 1 million deaths every year. Approximately 350 million are chronically infected with Hepatitis B worldwide. WHO estimated that approximately 170 million are infected with Hepatitis C. Together both Hepatitis B and Hepatitis C viruses are the leading causes of hepatocellular carcinoma in the world and accounts for $78 \%$ of cases. As both viruses are hepatotropic and causes progressive liver disease resulting in end stage so these should be screened out in each and every case by the method with more specificity and sensitivity so that right measures should be initiated at right time for its cure and to prevent its complications.

\section{Source of Funding}

None.

\section{Conflict of Interest}

None.

\section{References}

1. Petruzziello A, Marigliano S, Loquircio G, Cozzdino A, Caccipuoti C. Global epidemiology of Hepatitis $C$ virus infection: An up- date of distribution and circulation of Hepatitis C virus genotypes. World J Gastrenterol. 2016;22:7824-40.

2. Dhiman RK, Satsangi S, Grover GS, Puri P. Tackling the hepatitis $\mathrm{C}$ disease burden in Punjab, India. J Clin Exp Hepatol. 2016;6(3)224.

3. Alter HJ, Seeff LB. Recovery, persistence and sequelae in Hepatitis $\mathrm{C}$ virus infection: a perspective on long term outcome. Semin Liver Dis. 2000:20(1):17-35.

4. Puri P, Anand AC, Saraswat VA. Consensus statement of HCV task force of the Indian National Association for study of the liver (INASL). Part I: status report of HCV infection in India. $J$ Clin Exp Hepatol. 2014:4(2):106-16.

5. Sievert W, Altraif I, Razavi HA. A systematic review of Hepatitis C virus epidemiology in Asia, Australia and Egypt. Liver Int. 2011:31(suppl2):61-80.

6. Dhiman RK. Future of therapy for Hepatitis C in India. A matter of accessibility and affordability? J Clin Exp Hepatol. 2014:4(2):85-6.

7. Deguchi M, Yamashita N, Kagita M, Asari S, Iwatani Y, Tsuchida, et al. Quantitation of Hepatitis B surface antigen by an automated chemiluminescent microparticle immunoassay. $J$ Virol Methods. 2004;115:217-22.

8. Rupinder K Bakshi, Geeta Walia, Shikha Jain. Seroprevalence and risk factors of Hepatitis $\mathrm{B}$ and $\mathrm{C}$ virus infections among patients with chronic liver disease. J Gastro Infs. 2013;3(1):613.

9. Baseke J, Musenero M, Kizza HM. Prevalence of Hepatitis B and $\mathrm{C}$ and relationship to liver damage in HIV infected patients attending Joint Clinical Research Centre Clinic Kampala, Uganda. Afr Health Sci. 2015;15(2):322-7.

10. Bukhtiari N, Hussain T, Iqbal M, Malik AM, Qureshi AH, Hussain A. Hepatitis B and C single and co- infection in chronic liver disease and their effect on the disease pattern. $J$ Pak Med Assoc. 2003;53(4):136-40.

11. Devi KS, Singh NB, Mara J, Singh TB, Singh YM. Seroprevalence of Hepatitis B virus and Hepatitis C virus among hepatic disorders and injecting drug users in Manipur- a preliminary report. Indian J Microbiol. 2004;22(2):136-7.

12. Singh V, Katyal R, Kochhar RK, Bhasin DK, Aggarwal RP. Study of Hepatitis B and C viral markers in patients of chronic liver disease. Indian J Med Microbiol. 2004;22(4):269-70.

13. Chakravarti A, Verma V. Prevalence of Hepatitis C and B viral markers in patients with chronic liver disease : a study from Northern India. Indian J Med Microbiol. 2005;23(4):273-4.

14. Medhi GK, Mahanta J, Adhikary R, Akayam BS, Liegise B, Sarathy K, et al. Spatial distribution and characteristics of 
injecting drug users (IDU) in five North Eastern states of India. BMC Public Health. 2011:11:64.

15. Challenge PK, Borkakoty BJ, Chetia M, Das HK, Mahanta J. Risk of Hepatitis C infection among drug users in Mizoram, India. Indian J Med Res. 2008:128:640-6.

16. Singla N, Garg S, Gupta V, Chander J. Hepatitis C: An overview of its laboratory diagnosis. J Gastrointest Infect. 2013;3(1):9-11.

17. Suri P, Chinna D, Gupta V, Singh J, Chopra P, Singh R, et al. Seroprevalence of parenterally and enterally transmitted hepatitis viruses in a tertiary care hospital of North India- A two year study. J Gastro Infs. 2012;2:46- 51.

18. Panigrahi AK, Panda SK, Dixit RK, Rao KV, Acharya SK, Daborathy S, et al. Magnitude of Hepatitis C virus infections in
India; prevalence in healthy blood donors, acute and chronic liver disease. J Med Virol. 1997;51(3):167-74.

19. Sharma R, Sinha P, Bachiwal R, Rishi S. Seroprevalence of anti hepatitis $\mathrm{C}$ virus antibody in a hospital based population of Jaipur, Rajasthan. Indian J Community Med. 2007;32(2):158-9.

20. Mishra S, Chayani N, Sarangi G, Mallick B, Pati SB.

Seroprevalence of anti HCV antibody in and around Cuttack, Orissa. Indian J Microbiol. 2002;40-1.

How to cite: Kohli J, Puri A, Mahajan B. Seroreactivity of hepatitis B and C in a tertiary care hospital ASCOMS. Panacea J Med Sci. 2020;10(1):39-42. 